\title{
Inactivation of Akt by arsenic trioxide induces cell death via mitochondrial-mediated apoptotic signaling in SGC-7901 human gastric cancer cells
}

\author{
YAN-HUI GAO $^{1 *}$, HAO-PENG ZHANG ${ }^{2 *}$, SHU-MENG YANG $^{3}$, YUE YANG $^{4}$, \\ YU-YAN MA ${ }^{4}$, XIN-YU ZHANG ${ }^{2}$ and YAN-MEI YANG ${ }^{4}$
${ }^{1}$ The Center for Endemic Disease Control, Chinese Center for Disease Control and Prevention, Harbin Medical University;
${ }^{2}$ Department of Surgery, The Second Affiliated Hospital of Harbin Medical University, Harbin, Heilongjiang 150081;
${ }^{3}$ Department of Outpatient Surgery, Linyi People's Hospital, Linyi, Shandong 276003;
${ }^{4}$ Cancer Research Institute, Harbin Medical University, Harbin, Heilongjiang 150081, P.R. China

Received December 16, 2013; Accepted January 13, 2014

DOI: 10.3892/or.2014.2994

\begin{abstract}
Arsenic trioxide $\left(\mathrm{As}_{2} \mathrm{O}_{3}\right)$ has been recognized as a potential chemotherapeutic agent, yet the details concerning its mechanism of action in solid cancers remain undetermined. The present study assessed the role of Akt in the cell death induced by $\mathrm{As}_{2} \mathrm{O}_{3}$. The MTT assay showed that $\mathrm{As}_{2} \mathrm{O}_{3}$ suppressed the proliferation of SGC-7901 cells in a dose- and time-dependent manner. Characteristic apoptotic changes were observed in the $\mathrm{As}_{2} \mathrm{O}_{3}$-treated cells by Hoechst 33342 staining, and FACS analysis showed that $\mathrm{As}_{2} \mathrm{O}_{3}$ caused dose-dependent apoptotic cell death. $\mathrm{As}_{2} \mathrm{O}_{3}$ activated caspase-3 and -9 , and PARP cleavage in a dose-dependent manner. Compromised mitochondrial membrane potential and an increased protein level of Bax indicated involvement of mitochondia. $\mathrm{As}_{2} \mathrm{O}_{3}$ decreased the levels of p-Akt (Ser473), p-Akt (Thr308) and p-GSK-3 $\beta$ (Ser9), suggesting that $\mathrm{As}_{2} \mathrm{O}_{3}$ inactivated Akt kinase. In addition, LY294002 (a PI3 kinase inhibitor) augmented the apoptosis induced by $\mathrm{As}_{2} \mathrm{O}_{3}$. These results demonstrated that inhibition of PI3K/Akt signaling was involved in $\mathrm{As}_{2} \mathrm{O}_{3}$ induced apoptosis of gastric cancer SGC-7901 cells.
\end{abstract}

Correspondence to: Professor Yan-Mei Yang, Cancer Research Institute, Harbin Medical University, No. 6 Baojian Road, Nangang, Harbin, Heilongjiang 150081, P.R. China

E-mail: yangym0916@163.com

Professor Xin-Yu Zhang, Department of Surgery, The Second Affiliated Hospital of Harbin Medical University, No. 148 Baojian Road, Nangang, Harbin, Heilongjiang 150081, P.R. China

E-mail: xinyuzhang3052000@163.com

*Contributed equally

Key words: arsenic trioxide, Akt, apoptosis, mitochondrial membrane potential

\section{Introduction}

Gastric cancer has declined from the second to the fourth most common cancer in the world, yet it remains the second most common cause of cancer-related mortality among men and the fourth among women (1). It was estimated by the American Cancer Society that 989,600 new cases of gastric cancer and $\sim 738,000$ related deaths occurred in 2008 , with over $70 \%$ of new cases and deaths noted in developing countries (2). Gastric cancer is difficult to cure primarily since the majority of patients are diagnosed with advanced disease. It has been demonstrated that adjuvant therapy improves survival $(3,4)$. Unfortunately, there is no internationally accepted standard chemotherapy for advanced gastric cancer, and uncertainty remains regarding the choice of the optimal regimen $(5,6)$. Thus, the development of more efficacious therapies is critically needed for the treatment of this disease.

Arsenic trioxide $\left(\mathrm{As}_{2} \mathrm{O}_{3}\right)$, an inorganic compound of trivalent arsenic, has been used as a drug in traditional Chinese medicine for thousands of years (7). At present, it is recognized as a potent chemotherapeutic agent and has been approved by the Food and Drug Administration for the treatment of certain leukemias (8-10). Previous studies have demonstrated that $\mathrm{As}_{2} \mathrm{O}_{3}$ may have beneficial effects in the treatment of solid tumors including gastric cancer (11), hepatocellular carcinoma (12), breast cancer (13), lung cancer (14) and neuroblastoma (15); however, there are limitations to its application in the treatment of solid tumors owing to the necessity of high concentrations for antineoplastic efficacy $(16,17)$. Therefore, a better understanding of the underlying mechanisms of action of $\mathrm{As}_{2} \mathrm{O}_{3}$ may facilitate the development of strategies to induce therapeutic responses using lower concentrations of $\mathrm{As}_{2} \mathrm{O}_{3}(18)$.

Despite extensive research, the mechanism of action of $\mathrm{As}_{2} \mathrm{O}_{3}$ is not fully clear. Several studies have indicated that arsenic-induced apoptotic death may be crucial for its antileukemic action $(19,20)$. Specifically, the arsenic-induced apoptotic death process involves the reciprocal regulation of $\mathrm{Bcl}-2 / \mathrm{Bax}$, loss of mitochondrial membrane potential $(\Delta \psi \mathrm{m})$, activation of caspases, and fragmentation of DNA, 
suggesting that activation of mitochondrial-mediated intrinsic apoptotic signaling may play a major role in arsenic-induced death (21-23). However, with regard to solid tumors, it remains controversial whether apoptosis is involved in the cell death induced by $\mathrm{As}_{2} \mathrm{O}_{3}(11,24-26)$.

Although the process of apoptosis is mediated primarily by proteolytic activities, there is compelling evidence that signal transduction pathways involving specific protein kinases modulate the apoptotic response (27). The serine/threonine protein kinase (Akt, a member of the PI3K pathway) is involved in widely divergent cellular processes including apoptosis and cell proliferation (28). The aberrant activation of phosphoinositide 3-kinase (PI3K)/Akt has been documented as a frequent occurrence in human types of cancer $(29,30)$, and inhibition of this pathway should provide a therapeutic approach for cancer (31). Several studies indicate that $\mathrm{As}_{2} \mathrm{O}_{3}$-induced apoptosis is correlated with inactivation of PI3K/Akt in leukemia cells $(32,33)$. Furthermore, abnormal activation of the $\mathrm{PI} 3 \mathrm{~K} / \mathrm{Akt}$ pathway was found to render these cells resistance to $\mathrm{As}_{2} \mathrm{O}_{3}(34,35)$, and pharmacologic inhibitors of PI3K/Akt enhanced the apoptotic action of $\mathrm{As}_{2} \mathrm{O}_{3}$ (36). Therefore, inhibition of PI3K/Akt signaling may be critical for $\mathrm{As}_{2} \mathrm{O}_{3}$ action.

In the present study, we present data showing that $\mathrm{As}_{2} \mathrm{O}_{3}$-induced apoptosis was partly mediated via the activation of mitochondrial-mediated intrinsic apoptotic signaling, and $\mathrm{As}_{2} \mathrm{O}_{3}$ inactivated Akt kinase via dephosphorylation of Akt. In addition, we showed that LY294002 (a PI3 kinase inhibitor) enhanced the apoptosis induced by $\mathrm{As}_{2} \mathrm{O}_{3}$.

\section{Materials and methods}

Materials. $\mathrm{As}_{2} \mathrm{O}_{3}$ was purchased from Sigma Chemical Co. (St. Louis, MO, USA) and dissolved in $1 \mathrm{mmol} / 1$ $\mathrm{NaOH}$ as a $100-\mathrm{mM}$ stock solution. Antibodies against total Akt, phospho-Akt (Ser473), phospho-Akt (Thr308), phospho-GSK-3 $\beta$ (Ser9), poly(ADP-ribose) polymerase (PARP), cleaved PARP, pro-caspase-3, cleaved caspase-3, pro-caspase-9, cleaved caspase-9, $\beta$-actin and LY294002 (a PI3 kinase inhibitor) were purchased from Cell Signaling Technology, Inc. (Beverly, MA, USA). Antibodies against $\beta$-actin, Bcl-2 and Bax were purchased from Santa Cruz Biotechnology, Inc. (Santa Cruz, CA, USA). Alkaline phosphatase-linked secondary antibodies were purchased from Promega Corporation (Madison, WI, USA). Annexin V-fluorescein isothiocyanate (FITC)-labeled apoptosis detection kit was obtained from Baosai Biological Technology Co., Ltd. (Beijing, China). Hoechst 33342 and propidium iodide (PI) were purchased from Sigma Chemical Co.

Cell culture. The human gastric cancer SGC-7901 cell line (Heilongjiang Cancer Institute, China) was maintained in RPMI-1640 medium containing 10\% fetal bovine serum at $37^{\circ} \mathrm{C}$ in a $5 \% \mathrm{CO}_{2}$ atmosphere. All cell samples used were in the logarithmic growth phase.

Cell viability assay. The effect of $\mathrm{As}_{2} \mathrm{O}_{3}$ on the proliferation of SGC-7901 cells was assessed using the 3-(4,5-dimethylthiazol-2-yl)-2,5-diphenyltetrazolium bromide (MTT) conversion assay. Briefly, SGC-7901 cells were plated at 4x103 cells/well in 96-well plates for 16 to $20 \mathrm{~h}$. Then, the cells were exposed to varying concentrations of $\mathrm{As}_{2} \mathrm{O}_{3}$ at $37^{\circ} \mathrm{C}$ for 24,48 and $72 \mathrm{~h}$, respectively. Thereafter, $10 \mu \mathrm{l}$ of MTT $(5 \mathrm{mg} / \mathrm{ml})$ was directly added to each well, and the cells were incubated at $37^{\circ} \mathrm{C}$ for an additional $4 \mathrm{~h}$. After removal of the culture medium, the cells were lysed in $100 \mu \mathrm{l}$ of dimethyl sulfoxide (DMSO). The optical density (OD) at $490 \mathrm{~nm}$ was measured by a microplate reader (Bio-Rad, Hercules, CA, USA). The following formula was used: Relative percentage of cell viability $=(O D$ of the experimental sample/OD of the control group) $\mathrm{x} 100 \%$.

Assessment of mitochondrial membrane potential. Mitochondrial membrane potential $(\Delta \psi \mathrm{m})$ was quantified using Rhodamine 123, whose accumulation in the mitochondria of living cells depends on $\Delta \psi \mathrm{m}$. SGC-7901 cells $\left(1 \times 10^{6}\right)$ were collected after various treatments. Cells were washed and resuspended in $500 \mu 1$ of phosphate-buffered saline (PBS) buffer containing $5 \mu \mathrm{g} / \mathrm{ml}$ of Rhodamine 123 (Molecular Probes, Eugene, OR, USA), and were then incubated at $37^{\circ} \mathrm{C}$ for $30 \mathrm{~min}$ in the dark, washed and resuspended in PBS buffer. Finally, the intensity of the Rhodamine 123 staining was measured by flow cytometry with an excitation and emission setting of 488 and $530 \mathrm{~nm}$, respectively.

Apoptotic cell staining. Morphological evidence of apoptosis or necrosis was determined by Hoechst 33342 and PI nuclear staining. After the various treatments, the SGC-7901 cells were incubated with $5 \mu \mathrm{g} / \mathrm{ml}$ of Hoechst 33342 and $5 \mu \mathrm{g} / \mathrm{ml}$ PI for $15 \mathrm{~min}$ and then observed using fluorescence microscopy (Nikon TE2000-U, Japan) at a magnification of x200. Apoptotic cells were identified by characteristic unequivocal nuclear chromatin condensation and/or fragmentation (37). Digital images were captured from 5 random fields for each sample, and apoptotic cell counts were expressed as a percentage of the total number of nuclei counted.

Analysis of apoptosis by Annexin V-FITC staining. Early apoptosis was determined by staining cells with Annexin V-FITC. Briefly, after the various treatments, both floating and trypsinized adherent SGC-7901 cells were collected. Then the cell pellets were incubated with $5 \mu \mathrm{l}$ PI and $10 \mu \mathrm{l}$ Annexin V-FITC. The samples were then analyzed by flow cytometry.

Western blot analysis. After the various treatments, the SGC-7901 cells were collected and lysed in lysis buffer. The supernatants were then collected by centrifugation at $12,000 \mathrm{x}$ g for $5 \mathrm{~min}$ and analyzed for total protein content by the Bradford method. Equal amounts of lysate were loaded on a 10\% SDS-polyacrylamide gel. After electrophoresis, proteins were transferred to a nitrocellulose membrane, and the blots were probed by corresponding primary antibodies, followed by incubation with alkaline phosphatase (AP)-conjugated secondary antibodies (Promega Corporation). The positive bands representing protein were developed using the Western Blue Stabilized Substrate for Alkaline Phosphatase (Promega Corporation).

Statistical analyses. Data are expressed as means \pm SD of three repeated experiments. The one-way analysis of variance (ANOVA) was used for statistical analyses. $\mathrm{p}<0.05$ was considered to indicate a statistically significant result. All 
A

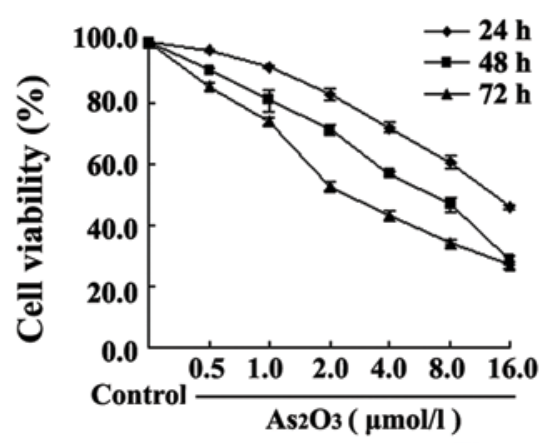

B Control

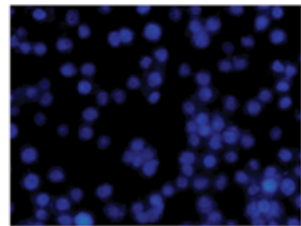

$4 \mu \mathrm{mol} / \mathrm{I}$

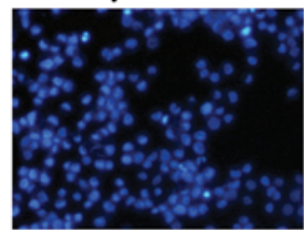

$1 \mu \mathrm{mol} / \mathrm{I}$

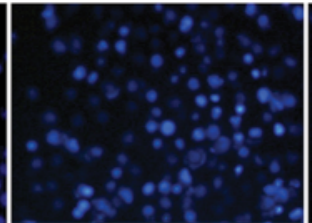

$8 \mu \mathrm{mol} / \mathrm{I}$

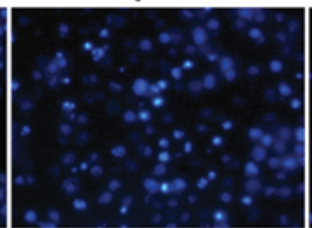

$2 \mu \mathrm{mol} / \mathrm{I}$

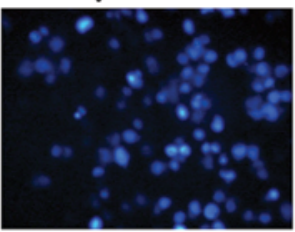

$16 \mu \mathrm{mol} / \mathrm{I}$

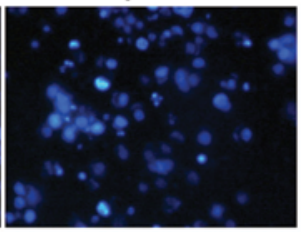

C
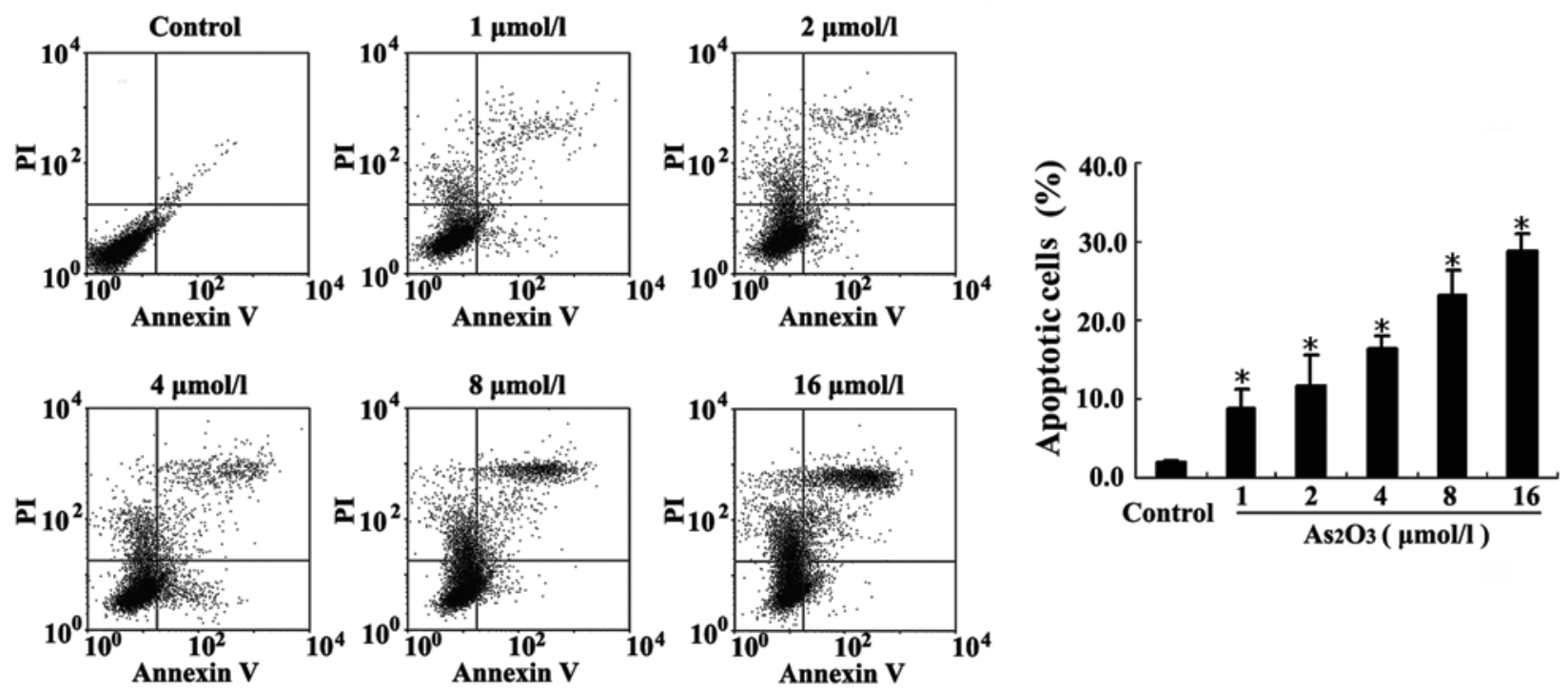

Figure 1. Effect of $\mathrm{As}_{2} \mathrm{O}_{3}$ treatment on cell growth and apoptosis. (A) Cell viability analysis. SGC-7901 cells were treated with As $\mathrm{O}_{3}(0-16 \mu$ mol/1) for 24,48 and $72 \mathrm{~h}$, and the cell growth was determined by MTT assay. Data shown are the mean \pm SD of 3 separate experiments for which each treatment was repeated in 96-well plates. (B and C) SGC-7901 cells were treated with $\mathrm{As}_{2} \mathrm{O}_{3}(0-16 \mu \mathrm{mol} / \mathrm{l})$ for $24 \mathrm{~h}$, and apoptosis was determined by fluorescence microscopy and flow cytometry as detailed in Materials and methods. (B) Morphological evidence of apoptosis or necrosis was determined by Hoechst 33342 and PI nuclear staining. Cells that stained blue with condensed chromatin and/or fragmentation were recorded as apoptotic cells. (C) Quantification of apoptosis by flow cytometry. The cells were labeled with Annexin-FITC and PI. Annexin V-positive cells were considered to be apoptotic cells, and their percentage is indicated. Data from 3 independent experiments are shown. ${ }^{*} \mathrm{p}<0.01$ vs. control. $\mathrm{As}_{2} \mathrm{O}_{3}$, arsenic trioxide; PI, propidium iodide.

experiments were performed at least three times independently.

\section{Results}

$\mathrm{As}_{2} \mathrm{O}_{3}$ reduces the proliferation of $\mathrm{SGC}-7901$ cells. To investigate the inhibitory effect of $\mathrm{As}_{2} \mathrm{O}_{3}$ on the proliferation of gastric cancer cells, SGC-7901 cells were treated with various concentrations of $\mathrm{As}_{2} \mathrm{O}_{3}(0$ to $16 \mu \mathrm{mol} / \mathrm{l})$ for 24,48 and $72 \mathrm{~h}$. The results of the MTT assay (Fig. 1A) demonstrated that $\mathrm{As}_{2} \mathrm{O}_{3}$ significantly inhibited cell viability in a dose- and time-dependent manner. The $50 \%$ inhibitory concentration $\left(\mathrm{IC}_{50}\right)$ of $\mathrm{As}_{2} \mathrm{O}_{3}$ was $3.32 \mu \mathrm{mol} / \mathrm{l}$ at $72 \mathrm{~h}$.

$\mathrm{As}_{2} \mathrm{O}_{3}$ induces the apoptosis of SGC-7901 cells through the mitochondrial pathway. To determined whether $\mathrm{As}_{2} \mathrm{O}_{3}$ inhibits the growth of SGC-7901 cells via induction of apoptosis, SGC-7901 cells were treated with $\mathrm{As}_{2} \mathrm{O}_{3}(0$ to $16 \mu \mathrm{mol} / \mathrm{l})$ for $24 \mathrm{~h}$, and apoptosis was determined using Hoechst 33342 staining. Characteristic apoptotic changes such as condensed, fragmented, and intensely fluorescent nuclei were observed in the SGC-7901 cells following treatment with $\mathrm{As}_{2} \mathrm{O}_{3}$ for $24 \mathrm{~h}$ (Fig. 1B). The extent of apoptosis was next quantified using flow cytometry with Annexin V and PI staining. $\mathrm{As}_{2} \mathrm{O}_{3}$ treatment for $24 \mathrm{~h}$ resulted in dose-dependent induction of apoptosis in the SGC-7901 cells (Fig. 1C).

To determine whether the mitochondrial pathway is involved in the induction of apoptosis induced by $\mathrm{As}_{2} \mathrm{O}_{3}$ treatment, changes in $\Delta \psi \mathrm{m}$ were measured by Rhodamine 123 staining and subsequent flow cytometry. With the increasing concentrations of $\mathrm{As}_{2} \mathrm{O}_{3}$, the numbers of SGC-7901 cells increased in the hypofluorescent portion, which indicated that $\mathrm{As}_{2} \mathrm{O}_{3}$ decreased the $\Delta \psi \mathrm{m}$ in SGC-7901 cells (Fig. 2A).

Since pro-apoptotic Bax and anti-apoptotic Bcl-2 play crucial roles in apoptosis, changes in the protein levels in the SGC-7901 cells treated with $\mathrm{As}_{2} \mathrm{O}_{3}$ were determined using western blotting. $\mathrm{As}_{2} \mathrm{O}_{3}$ did not significantly modify the protein level of Bcl-2, but increased the protein level of Bax 


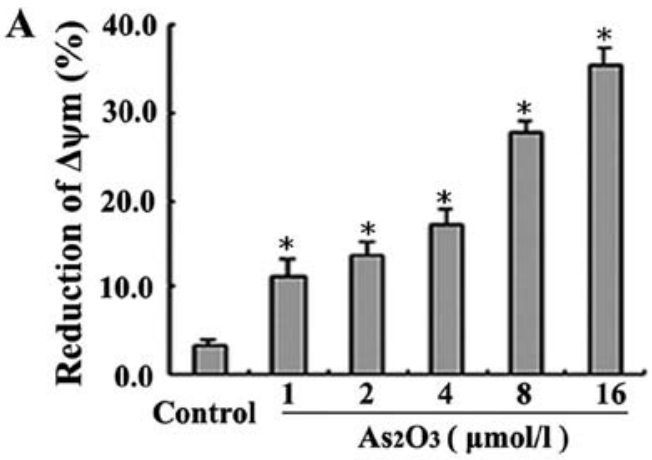

B

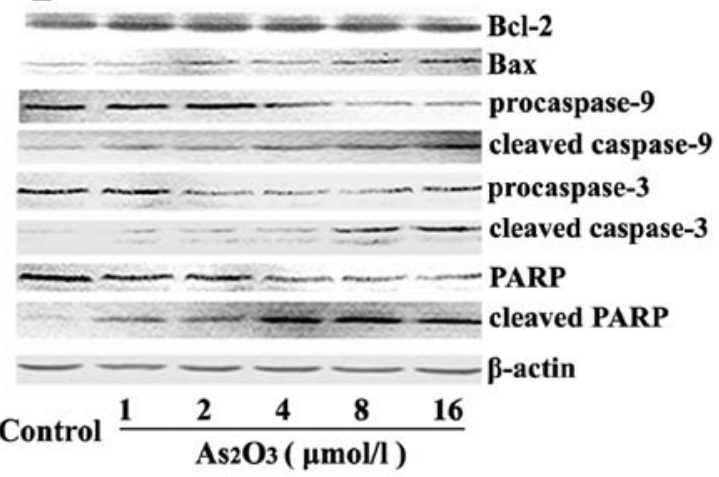

Figure 2. $\mathrm{As}_{2} \mathrm{O}_{3}$ induces the apoptosis of SGC-7901 cells through the mitochondrial pathway. (A) Assessment of mitochondrial membrane potential $(\Delta \psi \mathrm{m})$. SGC-7901 cells were treated with $\mathrm{As}_{2} \mathrm{O}_{3}(0-16 \mu \mathrm{mol} / \mathrm{l})$ for $24 \mathrm{~h}$, and Rhodamine 123 fluorescence was analyzed by flow cytometry. Data represent the percentage of cells with decreased fluorescence, which reflects the number of cells with low $\Delta \psi \mathrm{m}$. " $\mathrm{p}<0.01$ vs. control. (B) Analysis of the protein expression of Bax and Bcl-2, activation of caspase-3 and -9, and cleavage of PARP protein. SGC-7901 cells were incubated with $\mathrm{As}_{2} \mathrm{O}_{3}(0-16 \mu \mathrm{mol} / \mathrm{l})$ for $24 \mathrm{~h}$, and the levels of the proteins were analyzed by western blotting with antibodies against Bcl-2, Bax, pro-caspase-3, cleaved caspase-3, procaspase-9, cleaved caspase-9, PARP and cleaved PARP. $\mathrm{As}_{2} \mathrm{O}_{3}$, arsenic trioxide; PARP, poly(ADP-ribose) polymerase.

in a dose-dependent fashion (Fig. 2B), which resulted in an increase in the ratio of Bax to Bcl-2, therefore favoring apoptosis.

To determine whether the activation of caspase-3 and -9 is involved in the apoptosis induced by $\mathrm{As}_{2} \mathrm{O}_{3}$, the proteolytic maturation of pro-caspase- 3 and -9 was detected using western blotting. $\mathrm{As}_{2} \mathrm{O}_{3}$ treatment resulted in a decrease in the protein levels of pro-caspase- 3 and -9 and concomitant increase in the corresponding active cleavage products in the SGC-7901 cells (Fig. 2B), which indicated that $\mathrm{As}_{2} \mathrm{O}_{3}$ may increase the cleavage maturation of caspase- 3 and -9 . Meanwhile the cleavage of PARP, an executioner caspase substrate, was also detected using western blotting. Likewise, $\mathrm{As}_{2} \mathrm{O}_{3}$ treatment resulted in cleavage of PARP from 116 to $89 \mathrm{kDa}$ (Fig. 2B). Therefore, these results suggested that $\mathrm{As}_{2} \mathrm{O}_{3}$-induced apoptosis was partly mediated through the mitochondrial pathway.

$\mathrm{As}_{2} \mathrm{O}_{3}$ inhibits the phosphorylation of Akt in SGC-7901 cells. Akt has been reported to be involved in the signaling pathway mediated by $\mathrm{As}_{2} \mathrm{O}_{3}$, and its activation was found to be correxlated with phosphorylation at Thr308 and Ser473 residues. Therefore, the effects of $\mathrm{As}_{2} \mathrm{O}_{3}(0$ to $16 \mu \mathrm{mol} / \mathrm{l})$ treatment for $24 \mathrm{~h}$ on the amount and phosphorylation of Akt were evalu-

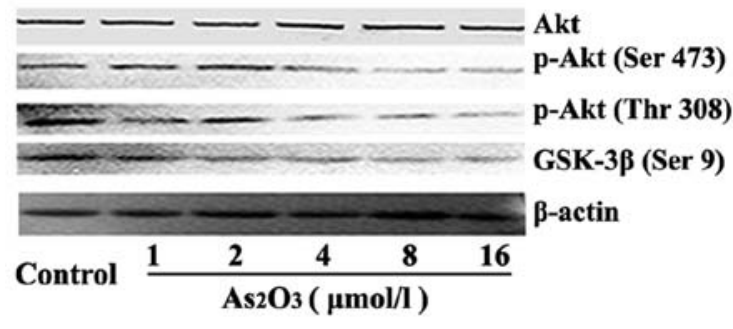

Figure 3. Effects of $\mathrm{As}_{2} \mathrm{O}_{3}$ on the activation and expression of Akt proteins Exponentially growing cells were treated with $\mathrm{As}_{2} \mathrm{O}_{3}(0-16 \mu \mathrm{mol} / \mathrm{l})$ for $24 \mathrm{~h}$, and the Akt, phospho-Akts and phosphoserine-9-GSK3 $\beta$ levels were evaluated using western blotting. $\mathrm{As}_{2} \mathrm{O}_{3}$, arsenic trioxide.

ated using western blotting. $\mathrm{As}_{2} \mathrm{O}_{3}$ did not significantly change the protein level of Akt, but decreased the levels of p-Akt (Ser473) and p-Akt (Thr308) (Fig. 3), which indicated that inactivation of Akt kinase following $\mathrm{As}_{2} \mathrm{O}_{3}$ treatment was due to dephosphorylation of $\mathrm{Akt}$, rather than reduction in total Akt protein. It was found that activated Akt phosphorylates and inactivates glycogen synthase kinase 3 (GSK-3), which plays an important role in the apoptotic pathway. Thus, changes in the phosphorylation of serine 9 of GSK $3 \beta$ were detected using an antibody that specifically recognizes phosphoserine9-GSK3 $\beta$. Likewise, a reduction in GSK3 $\beta$ phosphorylation was found in the SGC-7901 cells treated with $\mathrm{As}_{2} \mathrm{O}_{3}$ (Fig. 3), suggesting that $\mathrm{As}_{2} \mathrm{O}_{3}$ treatment decreases the activity of Akt.

PI3K/Akt inhibitor enhances the apoptosis induced by $\mathrm{As}_{2} \mathrm{O}_{3}$. To investigate whether the inhibition of PI3K/Akt signaling alters the extent of apoptosis induced by $\mathrm{As}_{2} \mathrm{O}_{3}$, LY294002 (a specific inhibitor of PI3K) was selected to inhibit PI3K/Akt signaling. Pretreatment with $25 \mu \mathrm{mol} / 1 \mathrm{LY} 294002$ for $1 \mathrm{~h}$ before exposure to $16 \mu \mathrm{mol} / 1 \mathrm{As}_{2} \mathrm{O}_{3}$ for $24 \mathrm{~h}$ completely blocked Akt activation (Fig. 4A). LY294002 significantly decreased the viability of the SGC-7901 cells from $60.0 \pm 1.0$ to $24.9 \pm 1.7 \%$ following treatment with $\mathrm{As}_{2} \mathrm{O}_{3}$ (Fig. 4B). LY294002 alone induced typical morphological changes and increased the percentages of the apoptotic population, which were greatly potentiated in the presence of $\mathrm{As}_{2} \mathrm{O}_{3}$ (Fig. 4C). Moreover, LY294002 significantly decreased $\Delta \psi \mathrm{m}$, which was further decreased in the presence of $\mathrm{As}_{2} \mathrm{O}_{3}$ (Fig. 4D). When $\mathrm{As}_{2} \mathrm{O}_{3}$ was used in combination with LY294002, the protein level of Bcl-2 was decreased, the protein level of Bax was significantly increased, the proteolytic activation of pro-caspase-3 and -9 was greatly potentiated, and the cleavage of PARP was enhanced. Therefore, LY294002 enhanced the extent of apoptosis induced by $\mathrm{As}_{2} \mathrm{O}_{3}$.

\section{Discussion}

$\mathrm{As}_{2} \mathrm{O}_{3}$ has attracted much attention due to its beneficial effects in the treatment of patients with acute promyelocytic leukemia (APL) without severe side-effects (38). Moreover, its antitumor activity has been confirmed in non-APL leukemia (9) and solid tumor cell lines $(16,25,39)$. $\mathrm{As}_{2} \mathrm{O}_{3}$ induces apoptosis and inhibits the growth of various types of tumor cells in vitro, but relatively higher concentrations are required for solid tumor cells than for hematologic cancer cells $(40,41)$. In the present study, we 
A

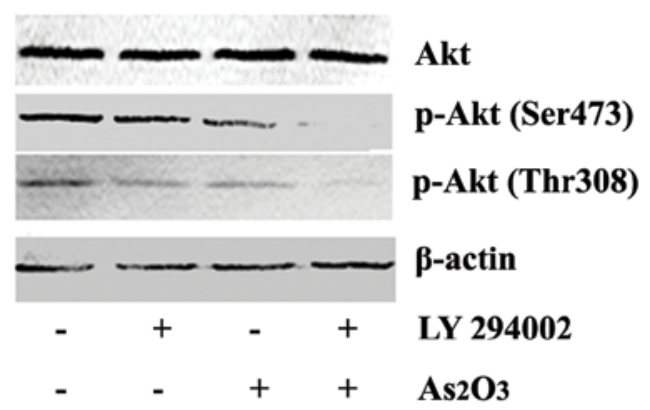

B
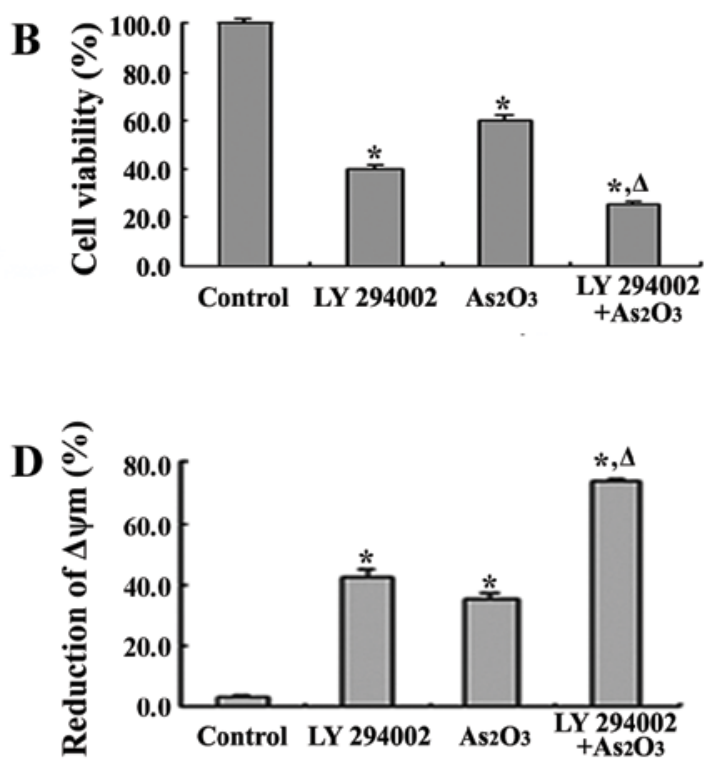

E

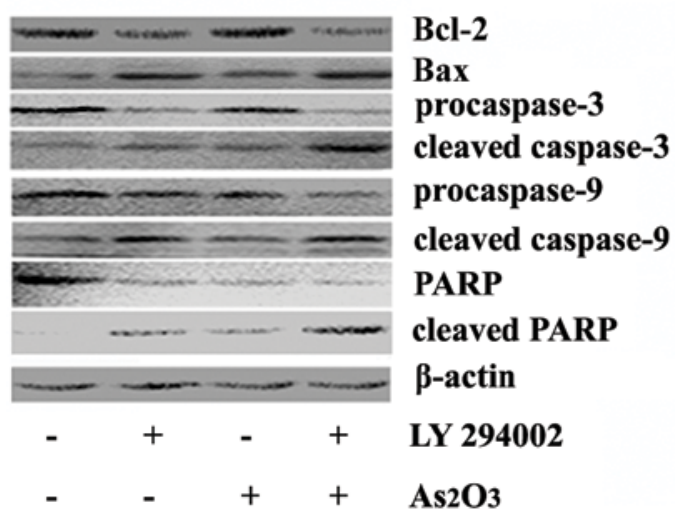

C

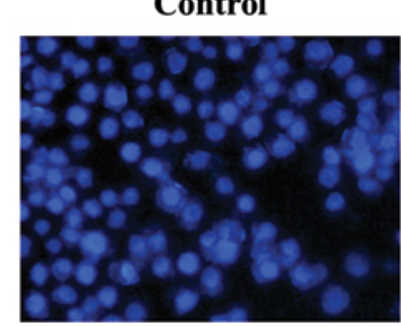

As2O3
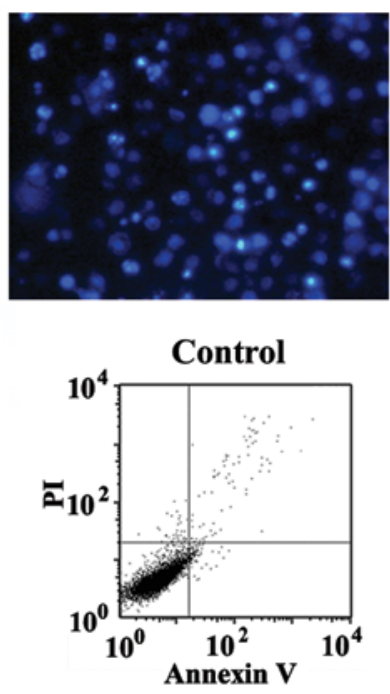

As2O3
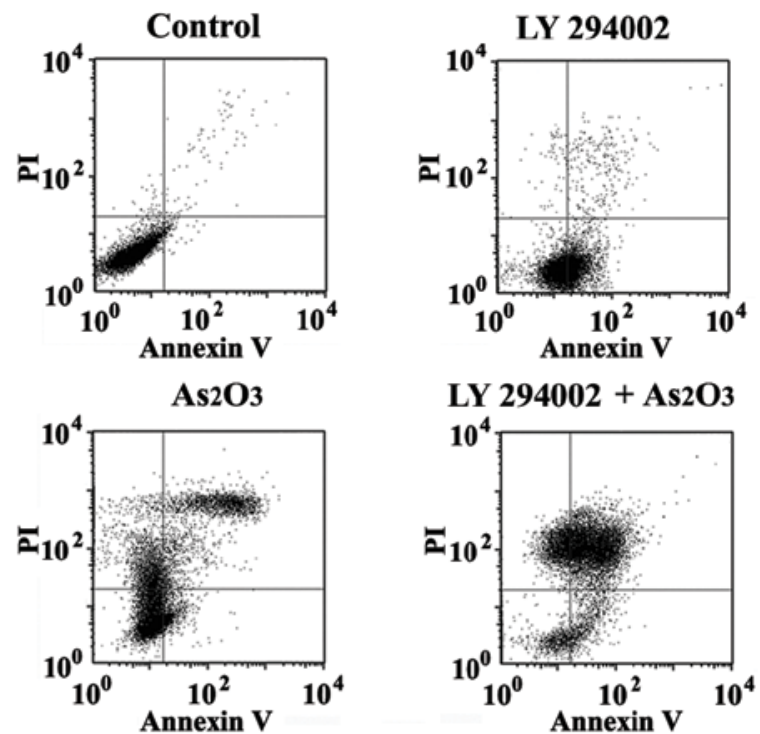

LY $294002+$ As2O3

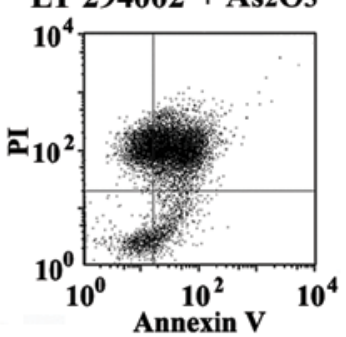

LY $294002+$ As2O3
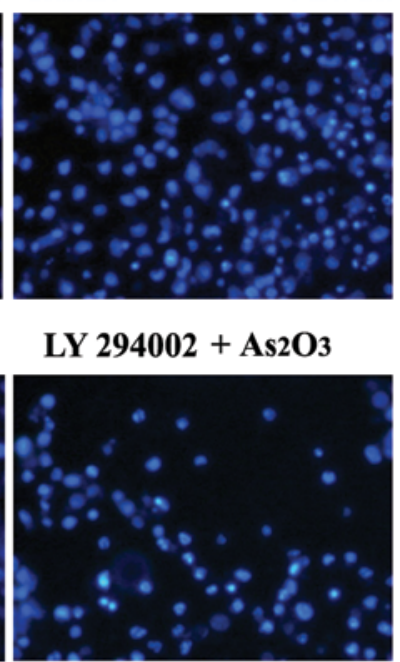

\section{(n)}


studies, which were performed in 8 APL patients successfully treated with $\mathrm{As}_{2} \mathrm{O}_{3}$, revealed that peak plasma concentrations rangeg from 5.54 to $7.30 \mu \mathrm{mol} / 1$ (38). Therefore, these results suggest that $\mathrm{As}_{2} \mathrm{O}_{3}$ may be clinically useful in patients with gastric cancer as an adjuvant chemotherapeutic agent. It has been indicated that the effective dose range of $\mathrm{As}_{2} \mathrm{O}_{3}$ being used to treat solid tumors in mice is from 2 to $6.5 \mathrm{mg} /$ $\mathrm{kg}(40,46)$. These dosages are 12 - to 40 -fold higher than the standard dosage of $0.16 \mathrm{mg} / \mathrm{kg}$ used to treat APL patients. Such high dosages carry the risk of severe side-effects due to toxicity $(40,47)$. Therefore, it is essential to determine the mechanisms of action of $\mathrm{As}_{2} \mathrm{O}_{3}$ and to develop strategies to enhance its efficacy.

The mechanisms responsible for the antitumor action of $\mathrm{As}_{2} \mathrm{O}_{3}$ have been extensively investigated. Apoptosis appears to be one of the main mechanisms by which $\mathrm{As}_{2} \mathrm{O}_{3}$ induces cell death and inhibits cell growth $(19,20,48)$. However, several studies indicate that $\mathrm{As}_{2} \mathrm{O}_{3}$ primarily induces arrest at the G1 or G2/M phases in solid cancer cells $(24,26,49)$. In support of these findings, our previous research found that $\mathrm{As}_{2} \mathrm{O}_{3}$ effectively inhibited the growth of hepatocellular carcinoma cells and induced G2/M phase arrest (50). In the present study, apoptotic morphological changes were observed in the nuclei of the SGC-7901 cells following treatment with $\mathrm{As}_{2} \mathrm{O}_{3}$, and FACS analysis showed that $\mathrm{As}_{2} \mathrm{O}_{3}$ caused dose-dependent apoptotic cell death. This result is similar to previous reports $(11,51)$. Consistent with a previous report (52), $\mathrm{As}_{2} \mathrm{O}_{3}$ increased active cleaved caspase-3 $(17 \mathrm{kDa})$ and cleaved fragment of PARP $(89 \mathrm{kDa})$. These results revealed that $\mathrm{As}_{2} \mathrm{O}_{3}$ has the capability to induce apoptosis in SGC-7901 cells.

Mitochondria play a key role in apoptotic signal transduction in mammalian cells (53). It has been suggested that $\mathrm{As}_{2} \mathrm{O}_{3}$ induces apoptosis in tumor cells by affecting the mitochondria, due to the loss of $\Delta \Psi \mathrm{m}$ (54-58) and cytochrome $c$ release from mitochondria $(59,60)$. In the present study, the loss of $\Delta \Psi \mathrm{m}$ was demonstrated by an increase in the proportions of cells with reduced Rhodamine 123 staining. Bcl-2 and Bax are members of the Bcl-2 family that regulate apoptosis by controlling mitochondrial integrity. Although they have highly similar amino acid sequences, their functions are opposed; Bcl-2 acts to inhibit apoptosis, whereas Bax counteracts this effect by heterodimerization with $\mathrm{Bcl}-2$. The ratio of $\mathrm{Bcl} / \mathrm{Bax}$ dictates the sensitivity of cells to apoptosis through destabilization of the mitochondrial membrane and activation of the caspase cascade (61). Zheng et al found that $\mathrm{As}_{2} \mathrm{O}_{3}$ triggered apoptosis through induction of Bcl-2 conformational change, Bax activation and upregulation of total Bax expression in human gastric cancer SGC7901 cells (11). In the present study, $\mathrm{As}_{2} \mathrm{O}_{3}$ had no effect on the protein level of Bcl-2, but increased the protein level of Bax in a dose-dependent fashion, thus increasing the ratio of Bax to Bcl-2. In mitochondrialdependent apoptosis, the disruption of the mitochondrion leads to the release of cytochrome $c$ into the cytosol. Apoptosomes containing cytochrome $c$, Apaf-1 and pro-caspase-9 are then assembled, resulting in proteolytic processing and activation of pro-caspase-9. Active caspase-9 in turn activates procaspase-3 initiating a caspase signaling cascade to induce apoptosis (62). In the present study, we also demonstrated that $\mathrm{As}_{2} \mathrm{O}_{3}$ induced apoptosis in parallel with the activation of caspase 9. Therefore, $\mathrm{As}_{2} \mathrm{O}_{3}$ has the ability to induce the mitochondrial-intrinsic apoptosis signaling pathway in gastric cancer.

Akt, a key mediator of the PI3K signaling pathway, promotes cell survival partially by phosphorylation and inactivation of several pro-apoptotic proteins, including GSK-3 (63), BAD (64) and caspase-9 (65). The role of Akt in $\mathrm{As}_{2} \mathrm{O}_{3}$-induced death has been investigated, yet the results are conflicting and confusing $(18,66,67)$. It has been found that the activity of the PI3K/Akt signaling pathway determines the sensitivity of leukemia cells to $\mathrm{As}_{2} \mathrm{O}_{3}$-induced apoptosis $(32,34,35)$. Moreover, pharmacologic inhibitors of PI3K/Akt were found to enhance the apoptotic action of $\mathrm{As}_{2} \mathrm{O}_{3}$ (36), while another report showed that pretreatment with inhibitors of PI3K had no effect on $\mathrm{As}_{2} \mathrm{O}_{3}$-induced apoptosis in the leukemic cell line NB4 (34). Our results showed that $\mathrm{As}_{2} \mathrm{O}_{3}$ decreased not only phosphorylated Akt protein levels but also Akt activity, which is coincident with a previous report (68). Meanwhile, we found that pretreatment with the PI3K/Akt inhibitor LY294002 strongly increased $\mathrm{As}_{2} \mathrm{O}_{3}$-induced apoptosis in SGC-7901 cells. Moreover, when $\mathrm{As}_{2} \mathrm{O}_{3}$ was used in combination with LY294002, $\Delta \psi \mathrm{m}$ was further decreased, the protein level of Bcl-2 was decreased, the protein level of Bax was significantly increased, the proteolytic activation of pro-caspase-3 and -9 was greatly potentiated, and the cleavage of PARP was enhanced, indicating that LY294002 enhanced the apoptosis induced by $\mathrm{As}_{2} \mathrm{O}_{3}$ via the mitochondrial-intrinsic apoptosis signaling pathway.

Taken together, our results suggest that $\mathrm{As}_{2} \mathrm{O}_{3}$ inactivated Akt kinase via dephosphorylation, which then induced apoptosis via activation of mitochondrial-mediated intrinsic apoptotic signaling. In addition, the PI3K inhibitor LY294002 enhanced the apoptosis induced by $\mathrm{As}_{2} \mathrm{O}_{3}$. Therefore, the PI3K/ Akt pathway plays a role in $\mathrm{As}_{2} \mathrm{O}_{3}$-induced death of SGC-7901 cells and the addition of PI3K inhibitors may be valuable for improving the efficacy of $\mathrm{As}_{2} \mathrm{O}_{3}$ treatment for human gastric cancer.

\section{Acknowledgements}

This study was supported by the Natural Science Foundation of Heilongjiang Province, China, grants (D2007-79), the National Natural Science Foundation of China (30800956,30972561) and the Heilongjiang Postdoctoral Science-Research Foundation.

\section{References}

1. Bertuccio $\mathrm{P}$, Chatenoud L, Levi F, et al: Recent patterns in gastric cancer: a global overview. Int J Cancer 125: 666-673, 2009.

2. Jemal A, Bray F, Center MM, Ferlay J, Ward E and Forman D: Global cancer statistics. CA Cancer J Clin 61: 69-90, 2011.

3. Macdonald JS, Smalley SR, Benedetti J, et al: Chemoradiotherapy after surgery compared with surgery alone for adenocarcinoma of the stomach or gastroesophageal junction. N Engl J Med 345: 725-730, 2001.

4. Cunningham D, Allum WH, Stenning SP, et al: Perioperative chemotherapy versus surgery alone for resectable gastroesophageal cancer. N Engl J Med 355: 11-20, 2006.

5. Scartozzi M, Galizia E, Verdecchia L, et al: Chemotherapy for advanced gastric cancer: across the years for a standard of care. Expert Opin Pharmacother 8: 797-808, 2007.

6. Wagner AD, Grothe W, Haerting J, Kleber G, Grothey A and Fleig WE: Chemotherapy in advanced gastric cancer: a systematic review and meta-analysis based on aggregate data. J Clin Oncol 24: 2903-2909, 2006. 
7. Emadi A and Gore SD: Arsenic trioxide - an old drug rediscovered. Blood Rev 24: 191-199, 2010.

8. Douer D and Tallman MS: Arsenic trioxide: new clinical experience with an old medication in hematologic malignancies. J Clin Oncol 23: 2396-2410, 2005.

9. Chen Z, Chen GQ, Shen ZX, et al: Expanding the use of arsenic trioxide: leukemias and beyond. Semin Hematol 39 (Suppl 1): S22-S26, 2002.

10. Sekeres MA: New data with arsenic trioxide in leukemias and myelodysplastic syndromes. Clin Lymphoma Myeloma 8 (Suppl 1): S7-S12, 2007.

11. Zheng Y, Zhou M, Ye A, Li Q, Bai Y and Zhang Q: The conformation change of $\mathrm{Bcl}-2$ is involved in arsenic trioxide-induced apoptosis and inhibition of proliferation in SGC7901 human gastric cancer cells. World J Surg Oncol 8: 31, 2010.

12. Fei M, Lu M, Wang Y, et al: Arsenic trioxide-induced growth arrest of human hepatocellular carcinoma cells involving FOXO3a expression and localization. Med Oncol 26: 178-185, 2009.

13. Chow SK, Chan JY and Fung KP: Inhibition of cell proliferation and the action mechanisms of arsenic trioxide $\left(\mathrm{As}_{2} \mathrm{O}_{3}\right)$ on human breast cancer cells. J Cell Biochem 93: 173-187, 2004.

14. Qu GP, Xiu QY, Li B, Liu YA and Zhang LZ: Arsenic trioxide inhibits the growth of human lung cancer cell lines via cell cycle arrest and induction of apoptosis at both normoxia and hypoxia Toxicol Ind Health 25: 505-515, 2009.

15. Karlsson J, Pietras A, Beckman S, Pettersson HM, Larsson C and Påhlman S: Arsenic trioxide-induced neuroblastoma cell death is accompanied by proteolytic activation of nuclear Bax. Oncogene 26: 6150-6159, 2007.

16. Park WH, Cho YH, Jung CW, et al: Arsenic trioxide inhibits the growth of A498 renal cell carcinoma cells via cell cycle arrest or apoptosis. Biochem Biophys Res Commun 300: 230-235, 2003.

17. Kanzawa $\mathrm{T}$, Kondo $\mathrm{Y}$, Ito $\mathrm{H}$, Kondo $\mathrm{S}$ and Germano I: Induction of autophagic cell death in malignant glioma cells by arsenic trioxide. Cancer Res 63: 2103-2108, 2003

18. Altman JK, Yoon P, Katsoulidis E, et al: Regulatory effects of mammalian target of rapamycin-mediated signals in the generation of arsenic trioxide responses. J Biol Chem 283: 1992-2001, 2008.

19. Miller WH Jr, Schipper HM, Lee JS, Singer J and Waxman S: Mechanisms of action of arsenic trioxide. Cancer Res 62: 3893-3903, 2002.

20. Zhou J: Arsenic trioxide: an ancient drug revived. Chin Med J 125: 3556-3560, 2012.

21. Mandegary A, Hosseini R, Ghaffari SH, et al: The expression of p38, ERK1 and Bax proteins has increased during the treatment of newly diagnosed acute promyelocytic leukemia with arsenic trioxide. Ann Oncol 21: 1884-1890, 2010.

22. Zheng Y, Yamaguchi H, Tian C, et al: Arsenic trioxide $\left(\mathrm{As}_{2} \mathrm{O}_{3}\right)$ induces apoptosis through activation of $\mathrm{Bax}$ in hematopoietic cells. Oncogene 24: 3339-3347, 2005.

23. Scholz C, Richter A, Lehmann M, Schulze-Osthoff K, Dörken B and Daniel PT: Arsenic trioxide induces regulated, death receptor-independent cell death through a Bcl-2-controlled pathway. Oncogene 24: 7031-7042, 2005.

24. Li Y, Qu X, Qu J, et al: Arsenic trioxide induces apoptosis and G2/M phase arrest by inducing Cbl to inhibit PI3K/Akt signaling and thereby regulate p53 activation. Cancer Lett 284: 208-215, 2009.

25. Han YH, Kim SZ, Kim SH and Park WH: Arsenic trioxide inhibits the growth of Calu- 6 cells via inducing a G2 arrest of the cell cycle and apoptosis accompanied with the depletion of GSH. Cancer Lett 270: 40-55, 2008.

26. Zhao S, Zhang J, Zhang X, Dong X and Sun X: Arsenic trioxide induces different gene expression profiles of genes related to growth and apoptosis in glioma cells dependent on the p53 status. Mol Biol Rep 35: 421-429, 2008.

27. Jarpe MB, Widmann C, Knall C, et al: Anti-apoptotic versus proapoptotic signal transduction: checkpoints and stop signs along the road to death. Oncogene 17: 1475-1482, 1998.

28. Franke TF, Hornik CP, Segev L, Shostak GA and Sugimoto C: PI3K/Akt and apoptosis: size matters. Oncogene 22: 8983-8998, 2003.

29. Bader AG, Kang S, Zhao L and Vogt PK: Oncogenic PI3K deregulates transcription and translation. Nat Rev Cancer 5: 921-929, 2005
30. Niedermeier M, Hennessy BT, Knight ZA, et al: Isoformselective phosphoinositide 3'-kinase inhibitors inhibit CXCR4 signaling and overcome stromal cell-mediated drug resistance in chronic lymphocytic leukemia: a novel therapeutic approach. Blood 113: 5549-5557, 2009.

31. Garcia-Echeverria C and Sellers WR: Drug discovery approaches targeting the PI3K/Akt pathway in cancer. Oncogene 27: 5511-5526, 2008

32. Redondo-Muñoz J, Escobar-Díaz E, Hernández Del Cerro M, et al: Induction of B-chronic lymphocytic leukemia cell apoptosis by arsenic trioxide involves suppression of the phosphoinositide 3-kinase/Akt survival pathway via $c$-jun- $\mathrm{NH}_{2}$ terminal kinase activation and PTEN upregulation. Clin Cancer Res 16: 4382-4391, 2010

33. Choi YJ, Park JW, Suh SI, et al: Arsenic trioxide-induced apoptosis in U937 cells involve generation of reactive oxygen species and inhibition of Akt. Int J Oncol 21: 603-610, 2002.

34. Tabellini G, Tazzari PL, Bortul R, et al: Phosphoinositide 3-kinase/Akt inhibition increases arsenic trioxide-induced apoptosis of acute promyelocytic and T-cell leukaemias. Br J Haematol 130: 716-725, 2005.

35. Tabellini G, Cappellini A, Tazzari PL, et al: Phosphoinositide 3-kinase/Akt involvement in arsenic trioxide resistance of human leukemia cells. J Cell Physiol 202: 623-634, 2005.

36. Ramos AM, Fernández C, Amrán D, Sancho P, de Blas E and Aller P: Pharmacologic inhibitors of PI3K/Akt potentiate the apoptotic action of the antileukemic drug arsenic trioxide via glutathione depletion and increased peroxide accumulation in myeloid leukemia cells. Blood 105: 4013-4020, 2005.

37. Dougherty CJ, Kubasiak LA, Prentice H, Andreka P, Bishopric NH and Webster KA: Activation of c-Jun N-terminal kinase promotes survival of cardiac myocytes after oxidative stress. Biochem J 362: 561-571, 2002.

38. Shen ZX, Chen GQ, Ni JH, et al: Use of arsenic trioxide $\left(\mathrm{As}_{2} \mathrm{O}_{3}\right)$ in the treatment of acute promyelocytic leukemia (APL): II. Clinical efficacy and pharmacokinetics in relapsed patients. Blood 89: 3354-3360, 1997.

39. Jiang X, Chen C, Zhao W and Zhang Z: Sodium arsenite and arsenic trioxide differently affect the oxidative stress, genotoxicity and apoptosis in A549 cells: an implication for the paradoxical mechanism. Environ Toxicol Pharmacol 36: 891-902, 2013.

40. Liu B, Pan S, Dong X, et al: Opposing effects of arsenic trioxide on hepatocellular carcinomas in mice. Cancer Sci 97: 675-681, 2006.

41. Hoffman E and Mielicki WP: Arsenic trioxide: impact on the growth and differentiation of cancer cells and possible use in cancer therapy. Postepy Hig Med Dosw 67: 817-827, 2013 (In Polish).

42. Xiao YF, Liu SX, Wu DD, Chen X and Ren LF: Inhibitory effect of arsenic trioxide on angiogenesis and expression of vascular endothelial growth factor in gastric cancer. World J Gastroenterol 12: 5780-5786, 2006.

43. Shao QS, Ye ZY, Ling ZQ and Ke JJ: Cell cycle arrest and apoptotic cell death in cultured human gastric carcinoma cells mediated by arsenic trioxide. World J Gastroenterol 11: 3451-3456, 2005.

44. Hayashi T, Hideshima T, Akiyama M, et al: Arsenic trioxide inhibits growth of human multiple myeloma cells in the bone marrow microenvironment. Mol Cancer Ther 1: 851-860, 2002.

45. Baj G, Arnulfo A, Deaglio S, et al: Arsenic trioxide and breast cancer: analysis of the apoptotic, differentiative and immunomodulatory effects. Breast Cancer Res Treat 73: 61-73, 2002.

46. Wu DD, Xiao YF, Geng Y and Hou J: Antitumor effect and mechanisms of arsenic trioxide on subcutaneously implanted human gastric cancer in nude mice. Cancer Genet Cytogenet 198: 90-96, 2010.

47. Soucy NV, Ihnat MA, Kamat CD, et al: Arsenic stimulates angiogenesis and tumorigenesis in vivo. Toxicol Sci 76: 271-279, 2003.

48. Wu YC, Yen WY and Yih LH: Requirement of a functional spindle checkpoint for arsenite-induced apoptosis. J Cell Biochem 105: 678-687, 2008.

49. Zhao S, Tsuchida T, Kawakami K, Shi C and Kawamoto K: Effect of $\mathrm{As}_{2} \mathrm{O}_{3}$ on cell cycle progression and cyclins D1 and $\mathrm{B} 1$ expression in two glioblastoma cell lines differing in p53 status. Int J Oncol 21: 49-55, 2002. 
50. Zhang X, Jia S, Yang S, Yang Y, Yang T and Yang Y: Arsenic trioxide induces $\mathrm{G} 2 / \mathrm{M}$ arrest in hepatocellular carcinoma cells by increasing the tumor suppressor PTEN expression. J Cell Biochem 113: 3528-3535, 2012.

51. Zhang Y, Cao EH and Qin JF: Up-regulation of telomere-binding TRF1, TRF2 related to reactive oxygen species induced by $\mathrm{As}_{2} \mathrm{O}_{3}$ in MGC-803 cells. Eur J Pharmacol 516: 1-9, 2005.

52. Jiang XH, Wong BC, Yuen ST, et al: Arsenic trioxide induces apoptosis in human gastric cancer cells through up-regulation of p53 and activation of caspase-3. Int J Cancer 91: 173-179, 2001.

53. Baysan A, Yel L, Gollapudi S, Su H and Gupta S: Arsenic trioxide induces apoptosis via the mitochondrial pathway by upregulating the expression of Bax and Bim in human B cells. Int J Oncol 30 : 313-318, 2007.

54. Paul MK, Kumar R and Mukhopadhyay AK: Dithiothreitol abrogates the effect of arsenic trioxide on normal rat liver mitochondria and human hepatocellular carcinoma cells. Toxicol Appl Pharmacol 226: 140-152, 2008.

55. Shen ZY, Shen J, Cai WJ, Hong $\mathrm{C}$ and Zheng MH: The alteration of mitochondria is an early event of arsenic trioxide-induced apoptosis in esophageal carcinoma cells. Int J Mol Med 5: $155-158,2000$

56. Shen ZY, Shen J, Li QS, Chen CY, Chen JY and Yi Z: Morphological and functional changes of mitochondria in apoptotic esophageal carcinoma cells induced by arsenic trioxide. World J Gastroenterol 8: 31-35, 2002.

57. Zhou J, Ye J, Zhao X and Li A: JWA is required for arsenic trioxide induced apoptosis in HeLa and $\mathrm{MCF}-7$ cells via reactive oxygen species and mitochondria linked signal pathway. Toxicol Appl Pharmacol 230: 33-40, 2008.

58. Selvaraj V, Armistead MY, Cohenford M and Murray E: Arsenic trioxide $\left(\mathrm{As}_{2} \mathrm{O}_{3}\right)$ induces apoptosis and necrosis-mediated cell death through mitochondrial membrane potential damage and elevated production of reactive oxygen species in PLHC-1 fish cell line. Chemosphere 90: 1201-1209, 2013.

59. Nutt LK, Gogvadze V, Uthaisang W, Mirnikjoo B, McConkey DJ and Orrenius S: Indirect effects of Bax and Bak initiate the mitochondrial alterations that lead to cytochrome $c$ release during arsenic trioxide-induced apoptosis. Cancer Biol Ther 4: 459-467, 2005 .
60. Zheng Y, Shi Y, Tian C, et al: Essential role of the voltagedependent anion channel (VDAC) in mitochondrial permeability transition pore opening and cytochrome $c$ release induced by arsenic trioxide. Oncogene 23: 1239-1247, 2004.

61. Uren RT, Dewson G, Chen L, et al: Mitochondrial permeabilization relies on $\mathrm{BH} 3$ ligands engaging multiple prosurvival $\mathrm{Bcl}-2$ relatives, not Bak. J Cell Biol 177: 277-287, 2007.

62. Chen M, Guerrero AD, Huang L, et al: Caspase-9-induced mitochondrial disruption through cleavage of anti-apoptotic BCL-2 family members. J Biol Chem 282: 33888-33895, 2007.

63. Crowder RJ and Freeman RS: Glycogen synthase kinase-3 $\beta$ activity is critical for neuronal death caused by inhibiting phosphatidylinositol 3-kinase or Akt but not for death caused by nerve growth factor withdrawal. J Biol Chem 275: 34266-34271, 2000.

64. Szanto A, Bognar Z, Szigeti A, Szabo A, Farkas L and Gallyas F Jr: Critical role of bad phosphorylation by Akt in cytostatic resistance of human bladder cancer cells. Anticancer Res 29: 159-164, 2009

65. Cardone MH, Roy N, Stennicke HR, et al: Regulation of cell death protease caspase- 9 by phosphorylation. Science 282: 1318-1321, 1998.

66. Chiu HW, Ho SY, Guo HR and Wang YJ: Combination treatment with arsenic trioxide and irradiation enhances autophagic effects in U118-MG cells through increased mitotic arrest and regulation of PI3K/Akt and ERK1/2 signaling pathways. Autophagy 5: 472-483, 2009.

67. Qian W, Liu J, Jin J, Ni W and Xu W: Arsenic trioxide induces not only apoptosis but also autophagic cell death in leukemia cell lines via up-regulation of Beclin-1. Leuk Res 31: 329-339, 2007.

68. Mann KK, Colombo M and Miller WH Jr: Arsenic trioxide decreases AKT protein in a caspase-dependent manner. Mol Cancer Ther 7: 1680-1687, 2008. 